\title{
Ship Exhaust Real-Time Monitoring System based on Automatic Identification System
}

\author{
Arnélio Sérgio Mabunda \\ Laboratoire d'Informatique, \\ Systèmes et \\ Télécommunications \\ Faculté des Sciences et \\ Techniques - Université \\ Abdelmalek Essaadi \\ Ancienne Route de l'Aéroport, \\ Km 10, Ziaten. BP: 416. Tanger - \\ Maroc
}

\author{
Abdelali Astito \\ Laboratoire d'Informatique, \\ Systèmes et \\ Télécommunications \\ Faculté des Sciences et \\ Techniques - Université \\ Abdelmalek Essaadi \\ Ancienne Route de l'Aéroport, \\ Km 10, Ziaten. BP: 416. Tanger - \\ Maroc
}

\author{
Salaheddine Hamdoune \\ Laboratoire d'Informatique, \\ Systèmes et \\ Télécommunications \\ Faculté des Sciences et \\ Techniques - Université \\ Abdelmalek Essaadi \\ Ancienne Route de l'Aéroport, \\ Km 10, Ziaten. BP: 416. Tanger - \\ Maroc
}

\begin{abstract}
Maritime traffic is a major source of pollutant gases and we believe that it is important to quantify these gases in order to assess their impact on the environment. This paper proposes a maritime monitoring system able to estimate in real time the emissions of carbon dioxide $\left(\mathrm{CO}_{2}\right)$ and particulate matter (PM) from ships crossing the Strait of Gibraltar area. The system works based on the Automatic Identification System (AIS) : it consists of an AIS receiver connected to a computer in which was installed an application able to determine, store and display emissions from ships. The computer application was performed according to a method for estimating $\mathrm{CO}_{2}$ and PM emissions from AIS data. The system was installed near the Strait of Gibraltar (exactly in Tangier - Morocco) and tests were carried out for about a month (between March 26 and April 23, 2014). The system recorded emissions from 900 to 4000 tons of $\mathrm{CO}_{2}$ and 2 to 9 tons of PM each day.
\end{abstract}

\section{Keywords}

Real-time system, ship emissions, maritime traffic, strait of Gibraltar

\section{INTRODUCTION}

Exhaust emissions from ships can be transported in the atmosphere over hundreds of kilometers and contribute to air quality problems inland [1], [2]. Automatic Identification System (AIS) is basically used by ships and Vessel Traffic Service (VTS) for monitoring maritime traffic, however, several studies were conducted to propose methods to calculate the amount of pollutant gases emitted by ships using AIS data [3] - [5]; but most of these methods use historical data (journeys carried by ships) and are not capable of providing real-time data.

The Strait of Gibraltar is a busy waterway, but at present, few studies have been conducted to know the level of pollutants gases emitted by ships crossing through this region. This paper proposes a system, operating in real time, able to estimate the amount of pollutant gases emitted by ships crossing the Strait of Gibraltar (the west of the Strait of Gibraltar and part of the northern Moroccan Atlantic coast). The system is based on a method for estimating carbon dioxide $\left(\mathrm{CO}_{2}\right)$ and particulate matter (PM) emissions using AIS data [6]. $\mathrm{CO}_{2}$ and $\mathrm{PM}$ are known respectively to be harmful to the environment (greenhouse gas) and human health (carcinogenic gas) [7], [8].

\section{MATERIALS AND METHODS}

\subsection{AIS receiver}

The Automatic Identification System (AIS) allows ships to broadcast regularly data within a range of about $70 \mathrm{~km}$ using radio waves (Very High Frequency - VHF). The AIS consist of an AIS transmitter which broadcasts data and an AIS receiver which receives data. The data sent by the AIS transmitter is : vessel type, length, width, draft, speed, geographical position, direction, destination, etc.

An AIS receiver was installed near the Strait of Gibraltar, exactly at the Faculty of Sciences and Technology of Tangier in Morocco ( $35^{\circ} 44^{\prime}$ 9.96" N, 5 53' 42.292" W). The AIS receiver is connected to a VHF antenna and covers the western of the Strait of Gibraltar and a part of the northern Atlantic coast of Morocco (figure 1). The received data is stored in a database and displayed in a Graphical User Interface - GUI (figure 1).

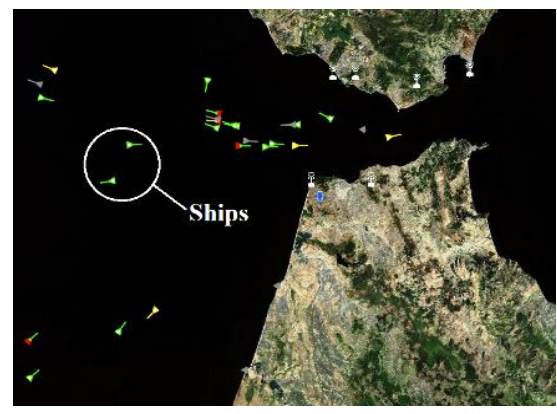

Fig 1: Screenshot of the system GUI showing ships crossing the Strait of Gibraltar on April 11, 2014 at 3:32 pm

\subsection{The method}

To estimate $\mathrm{CO}_{2}$ and PM emissions from ships, the method uses the following steps : AIS data (vessel type, length, width, draft, geographical position and navigation speed) is collected for each ship, and then, ship resistance, propulsion power, engine power output and fuel consumption are calculated using mathematical formulas; in the last step, $\mathrm{CO}_{2}$ and $\mathrm{PM}$ 
emissions are determined depending on fuel consumption and type. Figure 2 summarizes the steps of the method. More detail about this method is presented in [6].

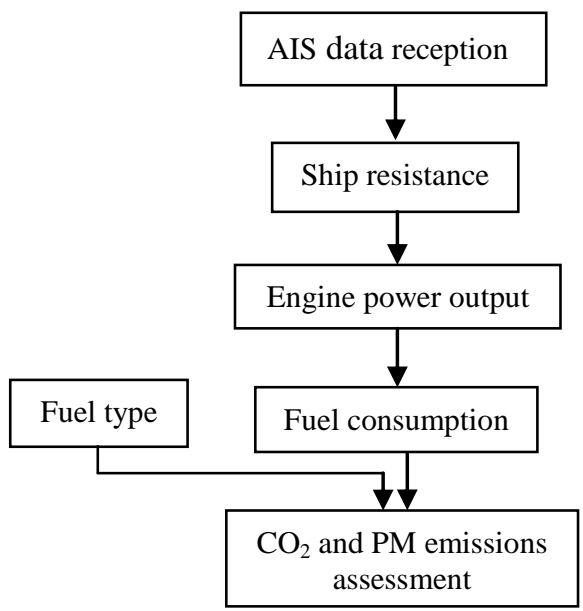

Fig 2: Stages of the method

This method is valid for cargo ships, tanker ships and passenger ships. The $\mathrm{CO}_{2}$ and PM emissions are those from the main engine, emissions from auxiliary engines and boilers are not taken into account.

\subsection{The $\mathrm{CO}_{2}$ and $\mathrm{PM}$ emissions estimator application}

The data captured by the AIS receiver is stored in a database (AIS Database) and then used by the computer application. The application estimates the $\mathrm{CO}_{2}$ and PM emissions on each ship, stores this data in a database (Emissions Database) and then displays it on a GUI (graphical user interface). Figure 3 shows the system operation scheme.

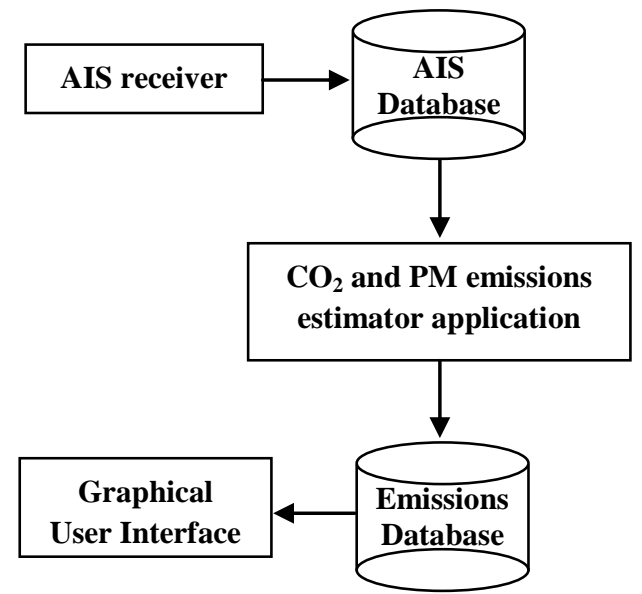

Fig 3: The system diagram

The AIS Database stores for each ship, data such as ship type, length, width, draft and speed, direction, location, etc. This data is used by the computer application as basic parameters for estimating the amount of $\mathrm{CO}_{2}$ and $\mathrm{PM}$ emitted by ships. The Emissions Database stores ship emissions data (the amount of $\mathrm{CO}_{2}$ and PM emitted every minute by a ship).

\section{RESULTS}

The system was installed near the Strait of Gibraltar and tested for 28 days (between March 26 and April 23, 2014). The data collected by the system gives information about maritime traffic and the amount of $\mathrm{CO}_{2}$ and $\mathrm{PM}$ generated by ships spotted in this area (blue area shown in figure 4).

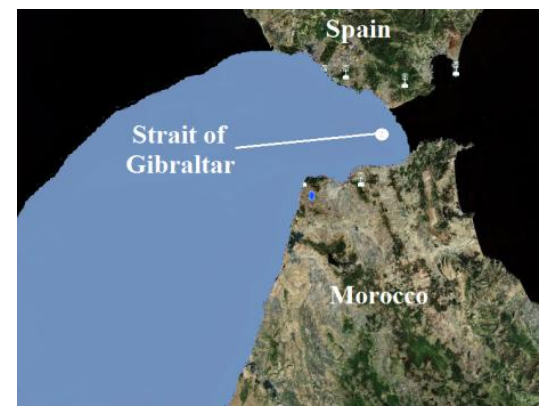

Fig 4: The area covered by the system (blue area)

\subsection{Maritime traffic}

During the trial period, the system recorded 4499 crossings of ships in which $2800(62.24 \%)$ are cargo ships, $1034(22.98 \%)$ tanker ships, $151(3.36 \%)$ passenger ships, $72(1.6 \%)$ other types of ship (military, pleasure craft and fishing) and 442 $(9.82 \%)$ unidentified ships (table 1). An unidentified ship is a ship transmitting AIS data without giving information about its type or size.

Table 1. Observed ship traffic by the system between March 26 and April 23, 2014

\begin{tabular}{|c|c|c|}
\hline Ship type & $\begin{array}{c}\text { Number of } \\
\text { crossings }\end{array}$ & Percentage \\
\hline Cargo & 2800 & $62.24 \%$ \\
\hline Tanker & 1034 & $22.98 \%$ \\
\hline Passenger & 151 & $3.36 \%$ \\
\hline Other type & 72 & $1.6 \%$ \\
\hline unidentified & 442 & $9.82 \%$ \\
\hline Total & 4499 & $100 \%$ \\
\hline
\end{tabular}

It is considered a crossing, when a ship is spotted in the system coverage area (blue area shown in figure 4) within a day. Figure 5 shows the daily traffic observed during the trial period.

\section{2 $\mathrm{CO}_{2}$ and PM emissions}

The $\mathrm{CO}_{2}$ and PM emissions data is given in real-time (data is refreshed every minute and given in kilograms per minute). Figures 6 and 7 show respectively the daily emissions (in tons per day) of $\mathrm{CO}_{2}$ and PM from cargo ships, tankers and passenger ships: the emissions are about 900 tons of $\mathrm{CO}_{2}$ and 2 tons of PM when traffic is relatively low (about 100 crossings per day) and about 4000 tons of $\mathrm{CO}_{2}$ and 9 tons of PM when traffic is high (over 200 crossings per day). Cargo ships, tankers and passenger ships contribute, respectively, about $73 \%, 23 \%$ and $4 \%$ of the emissions. 


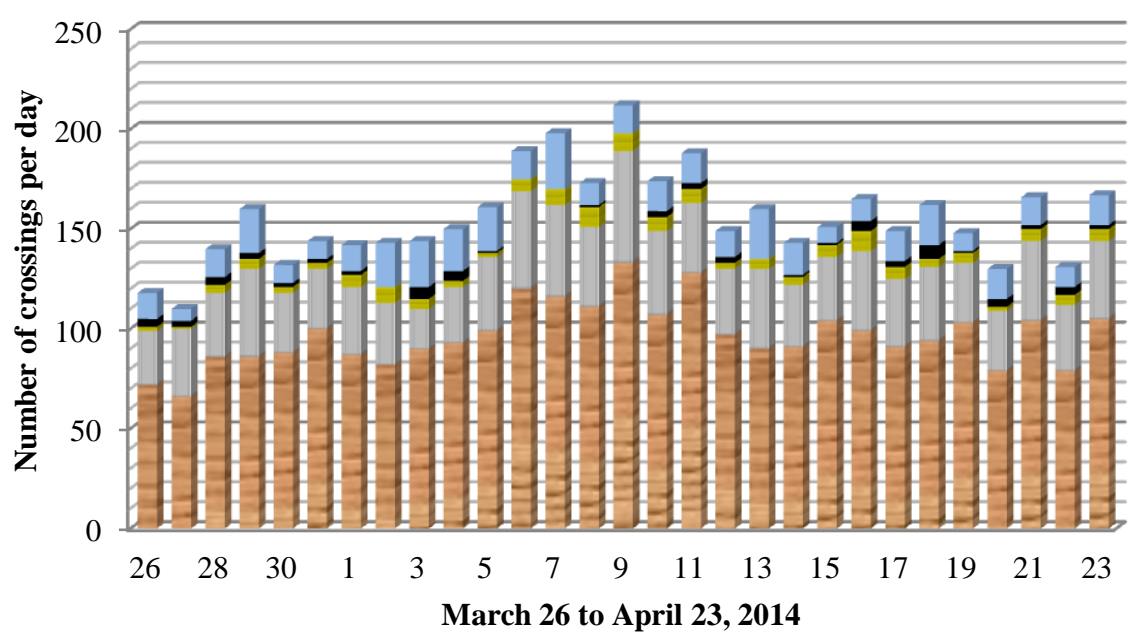

Fig 5: Observed daily traffic between March $26^{\text {th }}$ and April $23^{\text {rd }}, 2014$

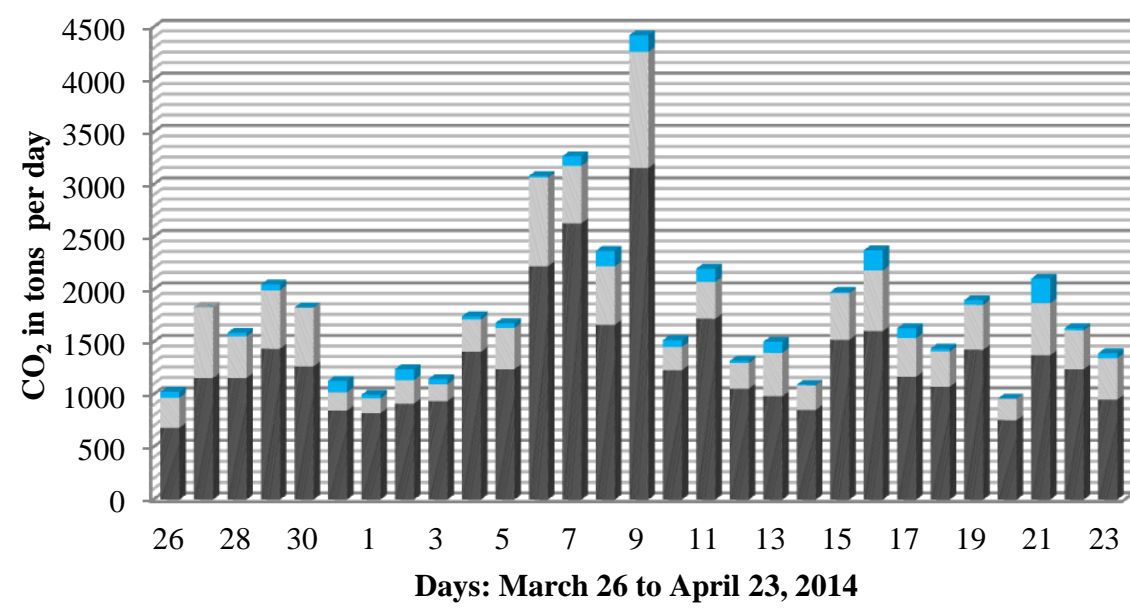

Fig 6: Estimated $\mathrm{CO}_{2}$ emissions between March $26^{\text {th }}$ and April $23^{\text {rd }}, 2014$

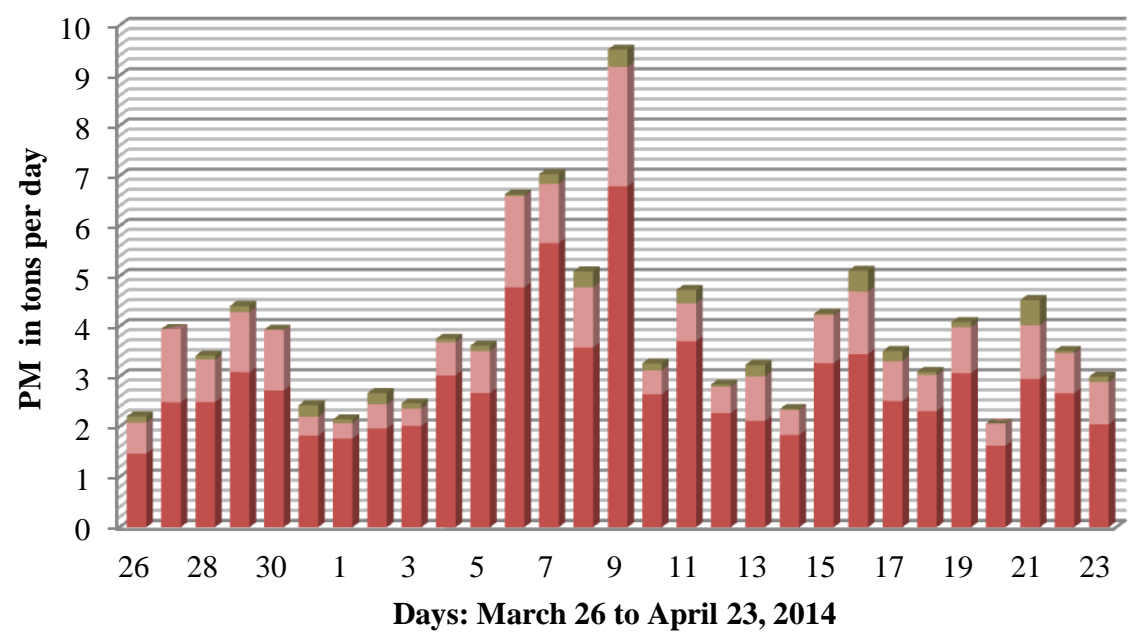

Fig 7: Estimated PM emissions between March 26 ${ }^{\text {th }}$ and April $23^{\text {rd }}, 2014$

\section{DISCUSSION}

The traffic observed during the trial period is dominated by cargo ships, tanker ships and passenger ships, they represent more than $88 \%$ of the all traffic, but it is important to note that this system only spots ships fitted with an AIS transmitter.
AIS is a mandatory system in all ships engaged on international voyages and whose gross tonnage exceeds 300 tons [9]; however, some small ships, including fishing and pleasure craft are not fitted with AIS, so they cannot be detected by the system. unidentified

other types

- passenger

III tanker

a cargo

\section{- passenger}

$\square$ tanker

- cargo

tanker

n cargo 
Figure 5 shows that traffic is high on certain days such as 9th April 2014 (over 200 crossings). High maritime traffic on the system is probably due to the radio wave propagation conditions through the troposphere (tropospheric ducting). Indeed, the range of the radio waves can be influenced by tropospheric ducting [10]: in theory, the range of the AIS signals (VHF waves) is about $70 \mathrm{~km}$, but when tropospheric ducting happen, the range of the AIS signals increases and the system is able to spot ships at more than $200 \mathrm{~km}$. So this phenomenon can increase greatly the number of ships detected by the system. However, it was found that when weather conditions are bad (strong wind, rough seas), such as $26^{\text {th }}$ March and $20^{\text {th }}$ April 2014, traffic is relatively low (about 120 crossings).

The $\mathrm{CO}_{2}$ and $\mathrm{PM}$ emissions are generally proportional to the maritime traffic intensity. However, $\mathrm{CO}_{2}$ and $\mathrm{PM}$ emissions presented in figures 6 and 7 do not necessarily follow the maritime traffic data shown in figure 5. This is due, firstly, to the fact that the data presented in figures 6 and 7 is the emissions from cargo ships, tankers and passenger ships only (the other ship types are not taken into account) and secondly, to the size of ships. Indeed, if one takes two days such as 21th and 23th April 2014, the number of crossings are similar (figure 5), but the $\mathrm{CO}_{2}$ and $\mathrm{PM}$ emissions (figures 6 and 7) are significantly different (emissions are higher on $21^{\text {th }}$ April). This can be explained by the size of the ships detected in these two days: from 166 ships detected on $21^{\text {th }}$ April, 35 ships have more than 100 meters length and from 167 ships detected on $23^{\text {th }}$ April only 20 ships have more than 100 meters length. So that leads us to believe that more the number of large ships is high, more the $\mathrm{CO}_{2}$ and $\mathrm{PM}$ emissions are high.

\section{CONCLUSION}

AIS was designed to monitor ship traffic but also to help ships reduce the risk of collision. The purpose of this study is, firstly, to show that the AIS data can also be used to quantify in real time the pollutant gases emitted by ships, and secondly, to assess the level of $\mathrm{CO}_{2}$ and $\mathrm{PM}$ emitted by ships crossing the Strait of Gibraltar area (the west of the Strait of Gibraltar and a part of the Moroccan Atlantic coast north). To achieve these goals, a monitoring maritime system based on AIS was developed.

The data provided by this system can be used to monitor emissions from ships crossing the Strait of Gibraltar and also to assess the impact of maritime traffic on air quality in this region [11].

So far, the method developed and used in this study only takes into account emissions from the main engines. We plan to improve this method to also be able to estimate emissions from auxiliary engines and boilers.

\section{REFERENCES}

[1] M. Viana, P. Hammingh, A. Colette, X. Querol, B. Degraeuwe, I. de Vlieger, et J. van Aardenne, «Impact of maritime transport emissions on coastal air quality in Europe », Atmos. Environ., vol. 90, p. 96-105, juin 2014.

[2] N. Kivekäs, A. Massling, H. Grythe, R. Lange, V. Rusnak, S. D. Carreno, H. Skov, E. Swietlicki, Q. T. Nguyen, M. Glasius, et A. Kristensson, «Contribution of ship traffic to aerosol particle concentrations downwind of a major shipping lane », Atmos Chem Phys Discuss, vol. 14, nº 6, p. 8419-8454, mars 2014

[3] P. S. Yau, S. C. Lee, J. J. Corbett, C. Wang, Y. Cheng, et K. F. Ho, «Estimation of exhaust emission from ocean going vessels in Hong Kong », Sci. Total Environ., vol. 431, p. 299-306, août 2012.

[4] J. Jalkanen, A. Brink, J. Kalli, et H. Pettersson, «A modelling system for the exhaust emissions of marine traffic and its application in the Baltic Sea area », Atmospheric Chem. Phys., vol. 9, $\mathrm{n}^{\mathrm{o}}$ 23, p. 9209-9223, 2009.

[5] T. Pitana, E. Kobayashi, et N. Wakabayashi, «Estimation of exhaust emissions of marine traffic using Automatic Identification System data (case study: Madura Strait area, Indonesia) », in OCEANS 2010 IEEE - Sydney, 2010, p. 1 -6.Forman, G. 2003. An extensive empirical study of feature selection metrics for text classification. J. Mach. Learn. Res. 3 (Mar. 2003), 12891305.

[6] A. S. Mabunda, A. Astito, et S. Hamdoune, « Estimating Carbon Dioxide and Particulate Matter Emissions from Ships using Automatic Identification System Data », Int. J. Comput. Appl., vol. 88, nº 6, p. 27-31, févr. 2014

[7] F.-M. Bréon et P. Ciais, « Spaceborne remote sensing of greenhouse gas concentrations ", Comptes Rendus Geosci., vol. 342, n $4-5$, p. 412-424, avr. 2010.

[8] Z. Cheng, J. Jiang, O. Fajardo, S. Wang, et J. Hao, «Characteristics and health impacts of particulate matter pollution in China (2001-2011) », Atmos. Environ., vol 65, p. 186-194, févr. 2013.

[9] International Maritime Organization, «SOLAS'1974, December 2000 amendments ».

[10] P. L. Slingsby, « Modelling tropospheric ducting effects on VHF/UHF propagation ", IEEE Trans. Broadcast. vol. 37, n 2, p. 25-34, juin 1991.

[11] M. Pandolfi, Y. Gonzalez-Castanedo, A. Alastuey, J. D. de la Rosa, E. Mantilla, A. S. de la Campa, X. Querol, J. Pey, F. Amato, et T. Moreno, «Source apportionment of PM10 and PM2.5 at multiple sites in the strait of Gibraltar by PMF: Impact of shipping emissions », Environ. Sci. Pollut. Res., vol. 18, $\mathrm{n}^{\circ} 2$, p. 260-269, 2011. 